\author{
S.A. Zabolotnykh ${ }^{1 *}$, M.G. Shcherban ${ }^{2}$, A.D. Solovyev ${ }^{2}$ \\ ${ }^{1}$ Institute of Technical Chemistry, Ural Branch of RAS, Perm, Russia; \\ ${ }^{2}$ Perm State National Research University, Russia \\ (Corresponding author's e-mail: zabolotsveta@mail.ru)
}

\title{
Effect of the hydrochloric acid concentration on the surface-active and functional characteristics of linear alkylbenzenesulfonic acid
}

\begin{abstract}
The surface-active (surface tension, adsorption, molecule cross-sectional area in the adsorption monomolecular layer) and colloidal (viscosity, critical micelle concentration, solubilization) properties in aqueous and hydrochloric acid solutions of anionic surfactant alkylbenzenesulfonic acid (ABSA) were studied. Surface activity of ABSA increases in the presence of hydrochloric acid. Two inflections were established on adsorption isotherms with inorganic acid content of 5 and $10 \mathrm{wt}$. \%, which are indicative of stepwise micelle formation. The ABSA dissociation is suppressed in the presence of hydrochloric acid, and therefore it behaves as a nonionic surfactant, forming micelles at lower concentrations. Mixed micelles, formed by dissociated and non-dissociated surfactant particles, are organized with an increase of ABSA content in mixture. The value of the surfactant limiting adsorption increases significantly at small hydrochloric acid amounts in comparison with an aqueous solution. The formed monomolecular layer is denser in the presence of inorganic acid than in an aqueous solution. The solubilization of Sudan I dye in alkylbenzenesulfonic acid increases with increasing in solution acidity. The extremum points on isotherms of solubilizing ability with 5 and $10 \mathrm{wt}$. \% $\mathrm{HCl}$ content are observed at surfactant concentrations corresponding to the beginning and end of the formation of micelles containing alkylbenzenesulfonate ion.
\end{abstract}

Key words: alkylbenzenesulfonic acid, surface tension, critical micelle concentration, hydrochloric acid, adsorption, monomolecular layer, solubilization, Sudan I.

\section{Introduction}

Alkylbenzenesulfonic acid (ABSA) is a raw material for the production of alkylbenzenesulfonates components of detergents, surfactants for ore flotation [1]. At the same time, ABSA itself is extremely rarely used in both enrichment [2,3] and ion flotation [4, 5], although it has many advantages: liquidity, mixes well with water, forms a stable foam, forms precipitates with metal ions, and is also a fairly affordable reagent.

To establish the possibility of using ABSA as a flotation reagent in acidic solutions, it is necessary to study the effect of the inorganic acids concentration on the surface-active and micellar properties of ABSA solutions [6].This work is devoted to the study of the colloidal properties of ABSA hydrochloric solutions.

\section{Experimental}

Alkylbenzenesulfonic acid is an anionic surfactant with the general formula $\mathrm{C}_{n} \mathrm{H}_{2 n+1} \mathrm{C}_{6} \mathrm{H}_{4} \mathrm{SO}_{3} \mathrm{H}$, $n=10-14$, the basic substance content is $96 \%$, and the average molecular weight is $320.9 \mathrm{~g} \cdot \mathrm{mol}^{-1}$. A stock solution of ABSK was prepared by dissolving an exact portion in distilled water. Solutions with a lower concentration were prepared by appropriate dilution. The hydrochloric acid content of 1,2,5 and 10 wt. \% was created by introducing the calculated amount of concentrated $\mathrm{HCl}\left(\rho=1.182 \mathrm{~g} \cdot \mathrm{mL}^{-1}\right.$, chemically pure).

All experiments were performed at $23{ }^{\circ} \mathrm{C}(296 \mathrm{~K})$. All the data, presented in the work, were obtained by averaging the results of three to four measurements.

The kinematic viscosity of the ABSA solutions was determined by SVM 3000 Stabinger viscometer (Anton Paar).

The surface tension at the «aqueous solution ABSA - air» interface was measured using a DSA 25E KRUSS tensiometer. The surface tension at various ABSA concentrations in model solutions containing 1,2, 5 , and $10 \mathrm{wt}$. $\% \mathrm{HCl}$ was measured similarly. The value of the surface tension at the «water-air» boundary at a given temperature was taken from the reference book [7].

The critical micelle concentrations (CMC) of ABSA at different $\mathrm{HCl}$ contents were determined from surface tension isotherms: in semilogarithmic coordinates they correspond to the points at which the curved

\footnotetext{
${ }^{*}$ Corresponding author
} 
section passes into a straight line parallel to the $\mathrm{X}$ axis [8]. Surface activity $(a)$ was calculated from the CMC value $\left(\mathrm{g} \cdot \mathrm{L}^{-1}\right)$ according to the formula:

$$
a=\frac{\sigma_{0}-\sigma_{C M C}}{C M C},
$$

where $\sigma_{0}-$ is the water surface tension; $\sigma_{C M C}-$ is the solution surface tension during CMC. formula:

The surface tension isotherms also were used to determine the specific adsorption $\left(G_{m}\right)$ of ABSA by the

where $R$ - is the universal gas constant.

$$
G_{m}=-\frac{1}{R T} \frac{\Delta \sigma}{\Delta \ln C}
$$

The area occupied by the ABSA molecule $\left(S_{0}\right)$ was calculated by the formula:

where $N_{A}$ - is the Avogadro constant.

$$
S_{0}=\frac{1}{G_{m} N_{A}}
$$

The solubilizing ability of ABSA was evaluated in relation to the oleophilic dye Sudan I (1-(phenylazo)-2-naphthol, chemically pure), insoluble in water, but soluble in the hydrophobic part of micelles. The dye content in the solution was determined by measuring the optical density of the solution in $0.5 \mathrm{~cm}$ cuvettes by UNICO spectrophotometer at $\lambda=400 \mathrm{~nm}$. Then, the amount of solubilized dye $\left(S, \mathrm{mg} \cdot \mathrm{L}^{-1}\right)$ in solution was determined using the calibration graph. The optical density of a dye solution (without surfactant) in benzene was measured to construct a calibration graph. For this, an exact weighed portion of the dye was introduced into $25 \mathrm{~mL}$ volumetric flask to create its concentration of 10, 20, 30, 40, $50,60 \mathrm{mg} \cdot \mathrm{L}^{-1}$, a certain benzene amount was added, stirred until the Sudan was dissolved, and the solution was brought to the mark with benzene. The optical densities were in the range $0.07 \div 0.95$. The molar solubilizing ability $\left(S_{m}\right)$ of ABSA solution was calculated as the ratio of the obtained $S$ value to the ABSA concentration $\left(c, g \cdot L^{-1}\right)[9]$ :

$$
S_{m}=\frac{S}{c}
$$

\section{Results and Discussion}

As can be seen from the Figure 1 (curve 1), the surface tension decreases sharply in the region of low ABSA concentrations, (to $34 \mathrm{mN} \cdot \mathrm{m}^{-1}, \mathrm{CMC}_{1}=0.74 \mathrm{~g} \cdot \mathrm{L}^{-1} \mathrm{ABSA}$ ). That represents the gradual filling process of the surface layer with surfactant molecules and reaching the adsorption limit value. After reaching a critical micelle concentration, the decrease in surface tension slows down with increasing ABSA content, that is associated with the micelles formation in the solution volume [10]. A further increase in the ABSA concentration, apparently, causes a transition from spherical micelles formed in solution at low surfactant concentrations to asymmetric, nonspherical micelles, which affects the surface layer state. These changes are also associated with the presence of a slight bend on the surface tension isotherm at $\sim 8.5 \mathrm{~g} \cdot \mathrm{L}^{-1}$ ABSA and a sharp increase in the solutions viscosity (Fig. 1, curve 2).

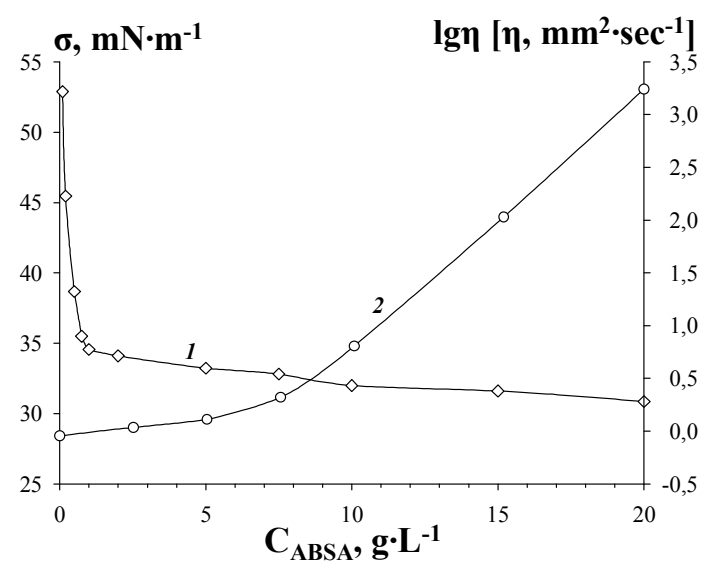

Figure 1. Isotherms of surface tension (1) and viscosity (2) of ABSA aqueous solutions 
The introduction of hydrochloric acid in concentrations of 1 and $2 \mathrm{wt} . \%$ leads to an increase in micelleforming ability, expressed in a decrease of CMC and surface tension during $\mathrm{CMC}$, that is caused by dehydration of the polar groups of the surface-active ions in the electrolyte presence (Fig. 2). Also, with an increase in the inorganic acid concentration, a decrease in the surface tension of the solutions begins with a lower ABSA content.

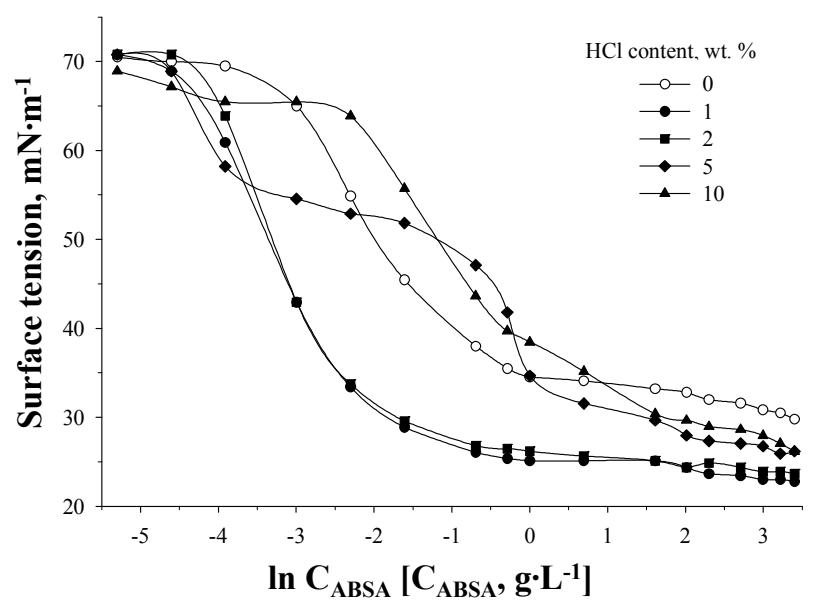

Figure 2. The effect of $\mathrm{HCl}$ content on surface tension isotherms of ABSA solutions

On the surface tension curves for 5 and 10 wt. \% hydrochloric acid, two bends are observed. Probably, with an increase of the inorganic acid concentration, the ABSA dissociation as a weaker acid $\left(\mathrm{p} K_{a}=2,17\right.$ [11]) is suppressed; as a result it behaves similarly to nonionic surfactant and forms premicellar structures in the region of lower concentrations [12]. As the ABSA content increases, the proportion of dissociated ABSA molecules (ABSA-anions) increases, which leads to the formation of mixed micelles, containing both dissociated and non-dissociated surfactant particles. These processes are accompanied by the appearance of another step on the surface tension isotherm. The obtained values of CMC depending on the medium ionic strength are presented in Table 1.

Ta b l e 1

The effect of ionic strength (I) on the surface-active characteristics of ABSA

\begin{tabular}{|c|c|c|c|c|}
\hline \multirow{2}{*}{$C, \mathrm{~mol} \cdot \mathrm{L}^{-1}(C$, wt. \%) } & \multirow{2}{*}{$\operatorname{lnCMC}\left[\mathrm{CMC}, \mathrm{g} \cdot \mathrm{L}^{-1}\right]$} & \multirow{2}{*}{$a, \mathrm{mN}^{2} \cdot \mathrm{m}^{2} \cdot \mathrm{kg}^{-1}$} \\
\cline { 2 - 4 } & & $\mathrm{CMC}_{1}$ & - & 50.30 \\
\hline $0(0)$ & 0 & -0.3 & - & 121.64 \\
\hline $0.29(1)$ & 0.29 & -1.0 & - & 158.48 \\
\hline $0.58(2)$ & 0.58 & -1.3 & 0.25 & 554.68 \\
\hline $1.45(5)$ & 1.45 & -3.5 & -0.28 & 386.72 \\
\hline $2.92(10)$ & 2.92 & -3.8 & \\
\hline
\end{tabular}

An increase of the medium acidity during the transition from water to $10 \mathrm{wt} . \% \mathrm{HCl}$, changes the conditions for the monomolecular layer formation, in comparison with an aqueous solution. That is reflected in the change of the height and maximum position on adsorption isotherms calculated from surface tension isotherms (Fig. 3). The initial injection of inorganic acid increases the value of the limiting adsorption sharply in comparison with appropriate aqueous solution. The further increase in the acid content lowers the value of the limiting adsorption, and it is achieved with smaller ABSA amounts.

This also argues in favor of the fact, that the monomolecular layer formation is facilitated with an increase of the $\mathrm{HCl}$ concentration. As a result, the molecules transition into volume occurs earlier with an increase in acidity. This process is accompanied by the appearance of desorption branches in solutions containing 5 and $10 \mathrm{wt} . \% \mathrm{HCl}$ and characteristic extremes on the adsorption isotherms. According to the calculations made on the obtained graphical dependences, the monomolecular layers, formed with the introduction of an inorganic acid, are denser than those formed in an aqueous solution (Table 2). However, the subsequent increase in the medium acidity leads to loosening of the monomolecular layer, what is expressed in the increase of the area occupied by one surfactant molecule in it. 


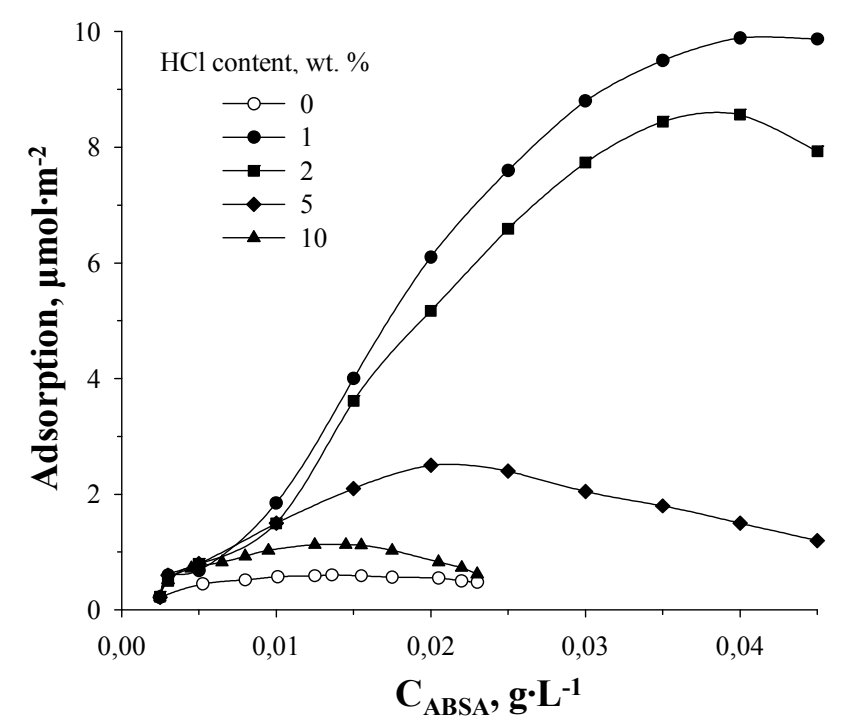

Figure 3. Adsorption isotherms at the «liquid - gas» interface in $\mathrm{HCl}$ solutions

Table 2

Influence of ionic strength on the parameters of the ABSA monomolecular layer at the «liquid - gas» interface

\begin{tabular}{|c|c|c|c|}
\hline $\mathrm{C}, \mathrm{mol} \cdot \mathrm{L}^{-1}(\mathrm{C}, \mathrm{wt} . \%)$ & $\mathrm{I}$ & $\mathrm{G}_{\max }, \mu \mathrm{mol} \cdot \mathrm{m}^{-2}$ & $\mathrm{~S}_{0} \cdot 10^{19}, \mathrm{~m}^{2}$ \\
\hline $0(0)$ & 0 & 0.61 & 27.39 \\
\hline $0.29(1)$ & 0.29 & 9.89 & 1.68 \\
\hline $0.58(2)$ & 0.58 & 8.56 & 1.94 \\
\hline $1.45(5)$ & 1.45 & 2.50 & 6.64 \\
\hline $2.92(10)$ & 2.92 & 1.13 & 14.70 \\
\hline
\end{tabular}

The solubilization mechanism is mainly determined by the surfactants nature. Containing polar groups oleophilic dye is introduced into the micelles surface layer in the case of ionogenic surfactants. Its molecules are located between surfactant molecules there, oriented parallel to them and transfer polar groups to the aqueous phase. In this case, the solubilizate can dissolve both in the core and in the hydrophilic shell of the micelles.

The calibration curve was constructed to determine the amount of dye solubilized by ABSA micelles (Fig. 4). It corresponds to the straight line equation obtained by the least squares method [13]:

$$
A=0.0147 \cdot C_{\text {dye }}\left(R^{2}=0.9983\right) \text {, }
$$

where $A$ - is the optical density; $C_{\text {dye }}$ - is Sudan I concentration, $\mathrm{mg} \cdot \mathrm{L}^{-1}$.

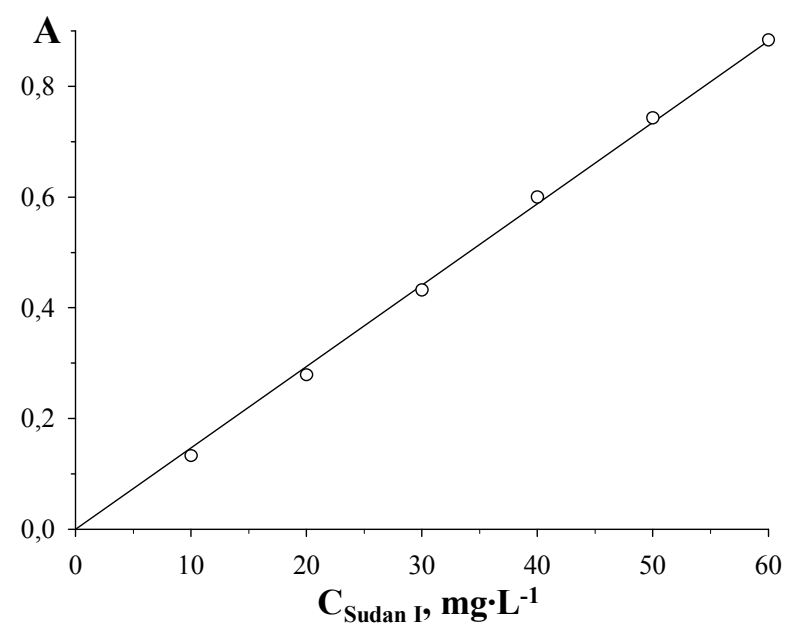

Figure 4. The calibration graph of Sudan I in benzene (UNICO, $\lambda=400 \mathrm{~nm}, l=0.5 \mathrm{~cm}$ ) 
The amount of solubilized dye slowly increases in the initial interval with increasing surfactant concentration. The solubilization isotherms in aqueous solution and in the presence of 1 and $2 \mathrm{wt}$ \% $\mathrm{HCl}$ practically match (Fig. 5a). The dye solubilization rise sharply with an increase in the ABSA content in a medium of 5 and $10 \mathrm{wt}$. \% inorganic acid. This is probably due to the transition from one type of micelle to another.

A sharp increase in the solubilizing ability is also observed at high concentrations of hydrochloric acid. Apparently, this is due to protonation of the dye and formation of an ionic associate with the ABSA-anion (Fig. 5b).
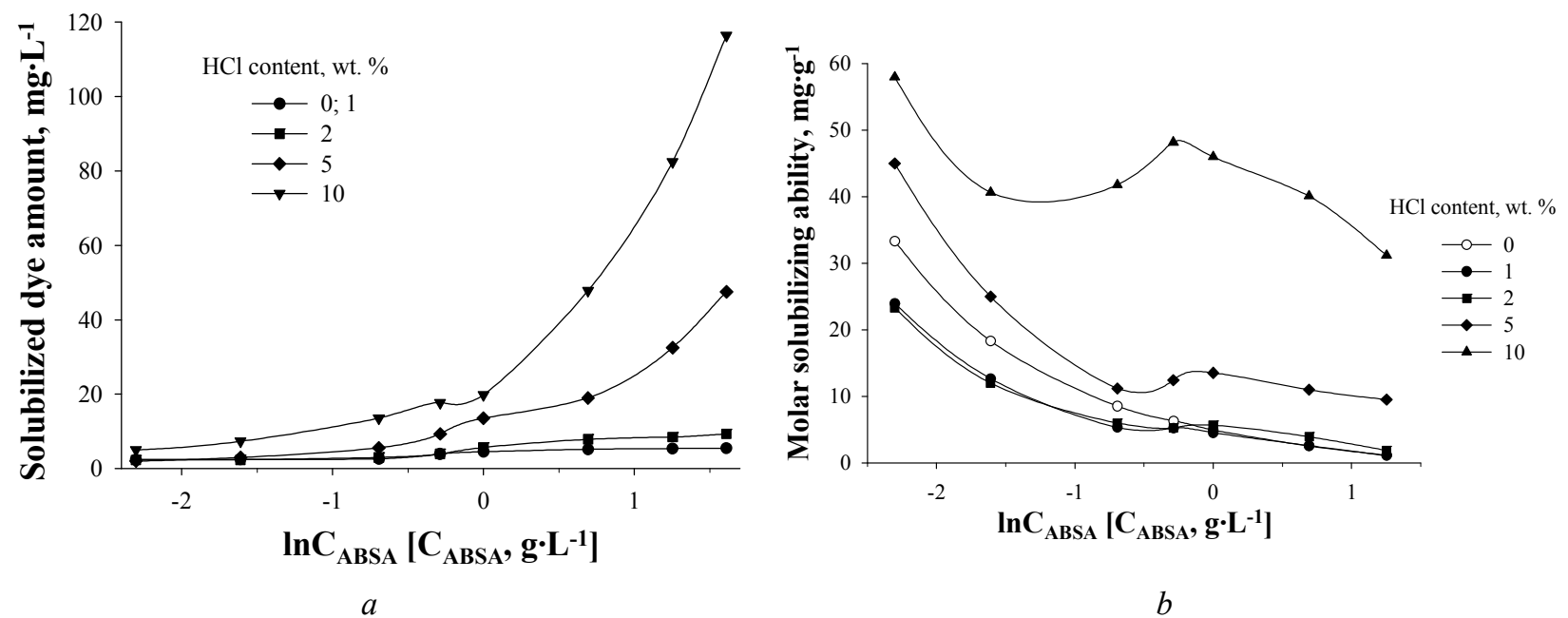

Figure 5. The effect of $\mathrm{HCl}$ content on the dye solubilization $(a)$ and the solubilizing ability of ABSA solutions $(b)$

Various additives affect colloidal dissolution especially, since they contribute to the micelles enlargement because of their hydrophobization (i.e., lowering the effective degree of dissociation and hydration) [14]. Highs and lows abscissa on isotherms of molar solubilizing ability at acidity of 5 and $10 \mathrm{wt} . \% \mathrm{HCl}$ coincide with the beginning and end of the formation of micelles containing the ABSA-anion, and the extremes severity increases with increasing concentration of hydrochloric acid (Table 3).

T a b le 3

Intervals of micelle formation based on ABSA anion and extrema abscissas on solubilizing ability curves

\begin{tabular}{|c|c|c|c|}
\hline \multirow{2}{*}{$C, \mathrm{~mol} \cdot \mathrm{L}^{-1}(C$, wt. \%) } & \multirow{2}{*}{ ABSA concentration range, $\mathrm{g} \cdot \mathrm{L}^{-1}(\ln C)$} & \multicolumn{2}{|c|}{ Extreme points, $\mathrm{g} \cdot \mathrm{L}^{-1}(\ln C)$} \\
\cline { 3 - 4 } & $0.05(-3.00)-0.74(-0.30)$ & Min & Max \\
\hline $0(0)$ & $0.50(-0.69)-1.00(0)$ & - & - \\
\hline $1.45(5)$ & $0.10(-2.30)-0.75(-0.28)$ & $0.50(-0.69)$ & $1.00(0)$ \\
\hline $2.92(10)$ & & $0.20(-1.60)$ & $0.75(-0.28)$ \\
\hline
\end{tabular}

\section{Conclusions}

Some conclusions can be drawn from the research results. The hydrochloric acid introduction changes the structure of the ABSA monomolecular layers and leads to an increase in its surface activity, expressed in a decrease in the critical micelle concentration value. Micelle formation proceeds in several stages in more concentrated hydrochloric acid solutions. In the region of low surfactant concentrations, ABSA dissociation is suppressed in acid medium and micelles, consisting mainly of undissociated molecules, are formed. With an increase in the ABSA content, mixed micelles are formed, containing ABSA-anions and undissociated acid. This correlates with the extrema positions on the solubilizing ability curves. A sharp increase in the solubilizing ability of ABSA in concentrated hydrochloric acid solutions in the studied range of surfactant concentrations can be caused by protonation of the dye and the formation of an ionic associate of the solubilizate with the ABSA anion.

The work was performed in accordance with the state task, state registration No. AAAA-A18118032790022-7. 
The work was carried out using the equipment of The Core Facilities Center «Research of materials and matter» at the Perm Federal Research Center of the Ural Branch of the Russian Academy of Sciences (PFRC UB RAS).

\title{
References
}

1 Абрамзон А.А. Поверхностно-активные вещества: справоч. / А.А. Абрамзон, В.В. Бочаров, Г.М. Гаевой. — Л.: Химия, 1979. - 376 с.

2 Брыляков Ю.Е. Применение алкилбензолсульфокислоты при флотации апатита из руд Хибинского месторождения / Ю.Е. Брыляков, М.Е. Быков, М.А. Кострова, Г.К. Паламарчук // Обогащение руд. — 2003. - № 5. — С. $19-21$.

3 Патент № 2318606 РФ. Способ флотации несульфидных руд / А.Ш. Гершенкоп, Г.А. Евдокимова, Ю.Е. Брыляков, Н.В. Воронина, Л.Л. Креймер // Опубл. БИ. 2008. № 2.

4 Абрютин Д.В. Перспективы применения процесса ионной флотации / Д.В. Абрютин, К.А. Стрельцова // Изв. высш. учеб. зав. «Цв. металлургия». — 2013. — № 3. - С. 3-6.

5 Медяник Н.Л. Удаление тяжелых металлов из растворов методом ионной флотации / Н.Л. Медяник, Н.К. Тусупбаев, И.А. Варламова, Х.Я. Гиревая, Н.Л. Калугина // Вестн. Магнитогор. гос. техн. ун-та им. Г.И. Носова. — 2016. — Т. 14 , № 1. - C. 18-26. DOI: 10.18503/1995-2732-2016-14-1-18-26

6 Радушев А.В. Физические и химические свойства N-(2-гидроксиэтил)алкиламинов / А.В. Радушев, Д.В. Колташев, Т.Ю. Насртдинова, М.Г. Щербань, Л.Г. Чеканова, М.Д. Плотникова // Журн. прикл. хим. — 2010. — Т. 83, Вып. 8. C. $1369-1373$.

7 Равдель А.А. Краткий справочник физико-химических величин / А.А. Равдель, А.М. Пономарева. — Л.: Химия, 1983. - $232 \mathrm{c}$.

8 Айвазов Б.В. Практикум по химии поверхностных явлений и адсорбции / Б.В. Айвазов. - М.: Высш. шк., 1973. $206 \mathrm{c}$.

9 Лабораторные работы и задачи по коллоидной химии / под ред. Ю.Г. Фролова и А.С. Гродского. — М.: Химия, 1986. $-216 \mathrm{c}$.

10 Холмберг К. Поверхностно-активные вещества и полимеры в водных растворах; пер. с англ. / К. Холмберг, Б. Йёнссон, Б. Кронберг, Б. Линдман. - М.: БИНОМ, 2007. — 528 с.

11 Заболотных С.А. Использование расслаивающейся системы «вода - антипирин - алкилбензолсульфокислота» для экстракции ионов металлов // С.А. Заболотных, В.О. Желнина, С.А. Денисова, А.М. Елохов, А.Е. Леснов // Журн. Сиб. федерал. ун-та. Сер. Химия. — 2017. — Т. 10, № 4. — С. 536-544. DOI: 10.17516/1998-2836-0047

12 Неудачина Л.К. Применение поверхностно-активных веществ в анализе: учеб. пос. / Л.К. Неудачина, Ю.С. Петрова. — Екатеринбург: Изд-во Урал. ун-та, 2017. — 76 с.

13 Булатов М.И. Практическое руководство по фотометрическим методам анализа / М.И. Булатов, И.П. Калинкин. Л.: Химия, 1986. - 432 с.

14 Демьянцева Е.Ю. Солюбилизация в растворах поверхностно-активных веществ: учеб.-метод. пос. / Е.Ю. Демьянцева, Р.А. Копнина. - СПб.: СПбГТУРП, 2015. - 31 с.

\section{С.А. Заболотных, М.Г. Щербань, А.Д. Соловьев \\ Хлорсутек қышқылы концентрациясының сызықтық алкилбензолсульфоқышқылының беттік-белсенді және функционалды сипаттамаларына әсері}

\begin{abstract}
Алкилбензолсульфоқышқылының (АБСК) беттік-белсенді (беттік керілу, адсорбция, адсорбциялық мономолекулалық қабаттағы молекуланың көлденең қимасының ауданы) және коллоидтық (тұтқырлық, мицелланың түзілуінің критикалық концентрациясы, солюбилизация) қасиеттері зерттелді. Хлорсутек қышқылының қатысында АБСК беттік-белсенділігі артады. Адсорбция изотермаларында бейорганикалық қышқыл мөлшері 5 және $10 \%$ болған кезде екі иілу сызығы көрінеді, бұл сатылы мицелланың пайда болуын көрсетеді. Хлорсутек қышқылының қатысында алкилбензолсульфоқышқылының диссоциациясы әлсірейді, осыған байланысты ол төмен концентрацияларда мицеллалар түзе отырып, иондық емес беттік-белсенді зат ретінде әрекет етеді. Қоспада алкилбензолсульфоқышқылының мөлшері ұлғайған сайын диссоциацияланған және диссоциацияланбаған беттік-белсенді заттың бөлшектерінен тұратын аралас мицеллалар пайда бола бастайды. Хлорсутек қышқылының аз мөлшерінде сулы ерітіндімен салыстырғанда беттік-белсенді заттың шекті адсорбциясының мәні едәуір артады. Сулы ерітіндіге қарағанда, бейорганикалық қышқыл қатысында пайда болған мономолекулалық қабат тығыз болады. Судан I бояғышының алкилбензолсульфоқышқылымен солюбилизациясы ерітіндінің қышқылдылығы артқан сайын ұлғаяды. Құрамында хлорсутек қышқылы 5 және $10 \%$ болғанда, солюбилизациялау қабілеті изотермаларында құрамында алкилбензолсульфонат — ионы бар мицеллалардың пайда болуының
\end{abstract}


басталуы мен аяқталуына сәйкес келетін беттік-белсенді зат концентрацияларының экстремумдары байқалды.

Кілт сөздер: алкилбензолсульфоқышқылы, беттік керілу, мицелла түзілуінің критикалық концентрациясы, хлорсутек қышқылы, адсорбция, мономолекулалық қабат, солюбилизация, судан I.

\title{
С.А. Заболотных, М.Г. Щербань, А.Д. Соловьев \\ Влияние концентрации хлороводородной кислоты на поверхностно-активные и функциональные характеристики линейной алкилбензолсульфокислоты
}

\begin{abstract}
Изучены поверхностно-активные (поверхностное натяжение, адсорбция, площадь поперечного сечения молекулы в адсорбционном мономолекулярном слое) и коллоидные (вязкость, критическая концентрация мицеллобразования, солюбилизация) свойства водных и солянокислых растворов анионного поверхностно-активного вещества (ПАВ) алкилбензолсульфокислоты (АБСК). В присутствии хлороводородной кислоты поверхностная активность АБСК увеличивается. На изотермах адсорбции при содержании неорганической кислоты 5 и 10 мас. \% установлено наличие двух перегибов, что свидетельствует о ступенчатом мицеллообразовании. В присутствии хлороводородной кислоты подавляется диссоциация алкилбензолсульфокислоты, в связи с чем она ведет себя как неионное ПАВ, образуя мицеллы при более низких концентрациях. С ростом содержания алкилбензолсульфокислоты в смеси появляются смешанные мицеллы, образованные частицами диссоциированного и недиссоциированного ПАВ. При малых количествах хлороводородной кислоты значительно увеличивается значение предельной адсорбции ПАВ по сравнению с водным раствором. В присутствии неорганической кислоты образующийся мономолекулярный слой является более плотным, чем в водном растворе. Солюбилизация красителя судана I алкилбензолсульфокислотой растет с повышением кислотности раствора. На изотермах солюбилизирующей способности при содержании хлороводородной кислоты 5 и 10 мас. \% наблюдаются экстремумы при концентрациях ПАВ, соответствующих началу и окончанию формирования мицелл, содержащих алкилбензолсульфонат-ион.
\end{abstract}

Ключевые слова: алкилбензолсульфокислота, поверхностное натяжение, критическая концентрация мицеллообразования, хлороводородная кислота, адсорбция, мономолекулярный слой, солюбилизация, судан I.

\section{References}

1 Abramzon, A.A., Bocharov, V.V., \& Gaevoy, G.M. (1979). Poverkhnostno-aktivnye veshchestva [Surfactants]. Leningrad: Khimiia [in Russian].

2 Brylyakov, Yu.Ye., Bykov, M.Ye., Kostrova, M.A., \& Palamarchuk, G.K. (2003). Primenenie alkilbenzolsulfokisloty pri flotatsii apatita iz rud Khibinskoho mestorozhdeniia [Application of alkylbenzene sodium sulfo-acid in flotation of the Khibini deposit apatite]. Obohashchenie rud - Ore dressing, 5, 19-21 [in Russian].

3 Gershenkop, A.Sh., Evdokimova, G.A., Bryljakov, Yu.Ye., Voronina, N.V., \& Kreimer, L.L. (2008). Patent No. 2318606 RF. Publ. BI, 2 [in Russian].

4 Abryutin, D.V., \& Streltsova, K.A. (2013). Perspektivy primeneniia protsessa ionnoi flotatsii [Prospects for the use of the ion flotation process]. Izvestiia vuzov. Tsvetnaia metallurhiia - Universities' Proceedings. Nonferrous Metallurgy, 3, 3-6 [in Russian].

5 Medyanik, N.L., Tussupbayev, N.K., Varlamova, I.A., Girevaya, Kh.Ya., \& Kalugina, N.L. (2016). Udalenie tiazhelykh metallov iz rastvorov metodom ionnoi flotatsii [Removing of Heavy Metals from Solutions by the Ion Flotation Method]. Vestnik Mahnitohorskoho hosudarstvennoho tekhnicheskoho universiteta im. H.I. Nosova - Vestnik of Nosov Magnitogorsk State Technical University, 14, 1, 18-26. DOI: 10.18503/1995-2732-2016-14-1-18-26 [in Russian].

6 Radushev, A.V., Koltashev, D.V., Nasrtdinova, T.Yu., Shcherban, M.G., Chekanova, L.G., \& Plotnikova, M.D. (2010). Fizicheskie i khimicheskie svoistva N-(2-hidroksietil)alkilaminov [Physical and chemical properties of N-(2-hydroxyethyl)alkylamines]. Zhurnal prikladnoi khimii - Journal of Applied Chemistry, 83, 8, 1369-1373 [in Russian].

7 Ravdel, A.A., \& Ponomareva, A.M. (1983). Kratkii spravochnik fiziko-khimicheskikh velichin [A quick reference to physical and chemical quantities]. Leningrad: Khimiia [in Russian].

8 Aivazov, B.V. (1973). Praktikum po khimii poverkhnostnykh yavlenii $i$ adsorbtsii [Workshop on the chemistry of surface phenomena and adsorption]. Moscow: Vysshaia shkola [in Russian].

9 Frolov, Yu.G., \& Grodskiy, A.S. (Eds.) (1986). Laboratornye raboty i zadachi po kolloidnoi khimii [Laboratory work and tasks in colloidal chemistry]. Moscow: Khimiia [in Russian].

10 Holmberg, K., Jonsson, B., Kronberg, B., \& Lindman, B. (2007). Poverkhnostno-aktivnye veshchestva i polimery v vodnykh rastvorakh [Surfactants and polymers in aqueous solutions]. Moscow: BINOM [in Russian].

11 Zabolotnykh, S.A., Zhelnina, V.O., Denisova, S.A., Elokhov, A.M., \& Lesnov, A.E. (2017). Ispolzovanie rasslaivaiushcheisia sistemy «voda - antipirin - alkilbenzolsulfokislota» dlia ekstraktsii ionov metallov [The Water - Antipyrine - 
Alkyl Benzene Sulfonic Acid Stratifying System to Extract Metal Ions]. Zhurnal Sibirskoho federalnoho universiteta. Seriia Khimiia - Journal of the Siberian Federal University. Series Chemistry, 10, 4, 536-544. DOI: 10.17516/1998-2836-0047 [in Russian].

12 Neudachina, L.K., \& Petrova, Yu.S. (2017). Primenenie poverkhnostno-aktivnykh veshchestv v analize [The use of surfaceactive substances in the analysis]. Ekaterinburg: Ural Univ. Publ. [in Russian].

13 Bulatov, M.I., \& Kalinkin, I.P. (1986). Prakticheskoe rukovodstvo po fotometricheskim metodam analiza [Practical guidance to photometric methods analysis]. Leningrad: Khimiia [in Russian].

14 Demyantseva, E.Yu., \& Kopnina, R.A. (2015). Soliubilizatsiia v rastvorakh poverkhnostno-aktivnykh veshchestv [Solubilization in solutions of surfactants]. Saint Petersburg: SPbGTURP [in Russian]. 